\title{
On the use of statistical techniques to assess the interrelationships of key water characteristics and plankton in the RIver Ganga at Veer-Bhadra Barrage
}

\author{
Vandana $^{1^{*}} \cdot$ Vasantika Kashyap ${ }^{2}$ \\ ${ }^{1}$ SGNP (Boys) Inter College Dehradun- 248001 Uttarakhand \\ ${ }^{2}$ Govt. PG College Uttarkashi \\ *Corresponding author: vandanakhanduri392@gmail.com
}

Received: 11.7.2021; Revised: 27.8.2021; Accepted:29.7.2021

OSociety for Himalayan Action Research and Development

\begin{abstract}
Past studies have demonstrated that some physico-chemical parameters play an important role in determining the quantity and quality of plankton in mountain (Himalayan) rivers. Due to their interplay they have well-defined statistical relationships. The present study assesses relationships among water temperature, $\mathrm{DO}, \mathrm{pH}, \mathrm{CO}_{2}$ and total alkalinity (TA) and plankton in the foothill section of the river Ganga at Veer-Bhadra barrage, Rishikesh. The correlation and regression analysis between showed linear +ve weak (non-significant) relationship for all abiotic factors except WT-DO. DO and TA show -ve linear insignificant relationship with plankton. Weak relationships suggests a perturbed ecosystem.
\end{abstract}

Keywords: Veer-Bhadra barrage, Physico-chemical parameters, Plankton, Statistical modelling.

\section{Introduction}

Most rivers of the Uttarakhand state are dammed for power generation, irrigation and industrial uses. One of them is Chilla Hydroelectric Power Project on the river Ganga between Rishikesh and Haridwar. The Veer-Bhadra barrage, diverts large amount of water into the Chilla canal and only little amount of water flows in the main stream of the Ganga river (Negi et al. 2006). This depletes the water discharge, influencing the physical, chemical and biotic characteristics.

The inter-relationships of physical, chemical and biotic characteristics of the mountain rivers have received little attention (Pathak et al. 1993), expressed mostly as ' $r$ ' the correlation coefficients (Bist 1993, Khanna et al 1993, Nautiyal et al 1993). The present study examines the interrelationships among physico-chemical factors and with plankton in the Veer-Bhadra barrage, near Rishikesh. Correlation and regression analysis is a set of statistical process for estimating the relationship between an independent variable and one or more dependent variables. The analysis of key abiotic factors and the biota using simple statistical techniques can indicate if modifying the river discharge for Hydroelectric Power Projects impacts the river or not. The kind of relationship as evidenced by degree of significance can be developed to grade the magnitude of impact.

\section{Methodology}

The river was sampled seasonally at VeerBhadra barrage (Rishikesh) during 2008-2009 and $2009-2010 \mathrm{~d} / \mathrm{s}$ of the barrage. The chemical factors viz water temperature (WT), $\mathrm{pH}$, dissolved oxygen (DO), $\mathrm{CO}_{2}$ and total alkalinity (TA) were recorded for the present investigations. The water temperature was 
measured using a simple centigrade thermometer. The $\mathrm{pH}$ of the sample was measured by pocket-pH meter. The DO was analysed by modified Winkler's method, while $\mathrm{CO}_{2}$ by neutralized phenolphthalein indicator method and the total alkalinity of a sample of water was determined by phenolphthalein and methyl orange indicator methods (Welch 1948). The plankton was collected by plankton net and fixed in $4 \%$ formalin for qualitative analysis. The initial identification of common species was done with the help of illustrated checklists. The number of taxa in each sample was recorded.

The data generated for said parameters was subjected to correlation and regression analysis using Data Analysis feature in Excel sheet. Correlation was performed to determine the nature of relationship (+ve/-ve), its significance and level thereof between two variables of concern. The regression analysis defines the degree to which the independent variable $(\mathrm{X})$ influences the dependent variable (Y) and predicts the influence of $\mathrm{X}$ on $\mathrm{Y}$. These analyses were performed on following six pair of abiotic variables and that of plankton with each abiotic variable. The relationship was examined between physical and chemical characteristics of high importance in Himalayan rivers viz. WT - DO, WT $-\mathrm{CO}_{2}, \mathrm{DO}-\mathrm{CO}_{2}, \mathrm{CO}_{2}-\mathrm{pH}, \mathrm{CO}_{2}-\mathrm{TA}$ and $\mathrm{pH}-\mathrm{TA}$. The relationship of plankton with each of these factors was also examined. Regression equations were obtained as 'intercept' and X - variable' from analysis in Excel sheet itself. Plots for each set of characteristics were prepared in MS Excel as scatter plot. Linear trend line was added by using Format Axis option in the sheet itself. The charts thus generated nature (+ve/-ve) of linear relationship.

\section{Results}

Correlation: Only WT - DO and $\mathrm{CO}_{2}-\mathrm{pH}$ exhibit $\mathrm{r}>0.5$, implying good relationship but lack statistical significance (95\% probability). Rest pairs showed very poor +ve relationship (Fig. 1). Notably, WT was found to be -vely correlated with $\mathrm{DO}$ and $\mathrm{CO}_{2}$ with TA. Plankton did not exhibit robust relationship with any of these parameters (Fig. 2). Relationship was mostly low and closer to $\mathrm{r}=$ 0.5 in case of TA followed by WT. Plankton was negatively correlated to DO and TA (Table 1).

Regression analysis: Straight line equations were obtained for all set of characteristics (Table 1). None except $\mathrm{CO}_{2}-\mathrm{pH}$, that was significant at $\mathrm{p}<0.05$, were found to influence the key abiotic characteristics. Also none influenced the plankton.

The abiotic factors are known to be interrelated (Hynes 1970); for instance water temperature affects DO and so does water current velocity and turbidity, for different reasons. Water current also controls the distribution of hard and soft substrate on the river bed. Apparently these (WT, WC and T) influence DO in the Himalayan rivers. Earlier studies have revealed that in Indian uplands certain abiotic factors significantly influence 
various forms of life occurring as different communities (Singh and Dobriyal 1981, Singh et.al., 1982, Nautiyal 1984, Dobriyal, 1985,
Dobriyal and Singh 1988, Pathak and Bhatt 1993, Rautela et.al., 2006) thus establishing the importance of WT, op cit, T and DO.

Table:1. Statistical data of interrelationships between some important water characteristics and plankton (WT - water temperature, DO- dissolved oxygen, $\mathrm{CO}_{2}$ - carbon dioxide, pH, TA - Total alkalinity)

\begin{tabular}{|c|c|c|c|c|c|}
\hline Abiotic factors & Correlation coefficient $(\mathbf{r}) /$ & $\mathbf{R}^{2}$ & $\begin{array}{l}\text { Regression } \\
\text { equation }\end{array}$ & ANOVA (F) & Significance (F) \\
\hline WT - DO & -0.596 & 0.355 & $\begin{array}{l}Y=- \\
0.1291 X+4.3176\end{array}$ & 4.413 & 0.069 \\
\hline $\mathrm{WT}-\mathrm{CO}_{2}$ & 0.1035 & 0.0107 & $\begin{array}{l}\mathrm{Y}= \\
0.0179 \mathrm{X}+1.1379\end{array}$ & 0.087 & 0.776 \\
\hline $\mathrm{DO}-\mathrm{CO}_{2}$ & 0.2453 & 0.060 & $y=0.196 x+1.090$ & 0.512 & 0.494 \\
\hline $\mathrm{CO}_{2}-\mathrm{pH}$ & 0.6278 & 0.394 & $Y=1.2743 X+6.2068$ & 5.2 & 0.05 \\
\hline $\mathrm{CO}_{2}-\mathrm{TA}$ & -0.115 & 0.0134 & $\begin{array}{l}Y=-0.0023 X+ \\
1.6555\end{array}$ & 0.109 & 0.75 \\
\hline pH-TA & 0.376 & 0.142 & $\begin{array}{l}Y=9.3164 X+ \\
5.2233\end{array}$ & 1.319 & 0.284 \\
\hline \multicolumn{6}{|l|}{ Plankton } \\
\hline WT- Plankton & 0.3924 & 0.154 & $\begin{array}{l}\mathrm{Y}= \\
0.3419 \mathrm{X}+3.0752\end{array}$ & 1.456 & 0.262 \\
\hline DO- Plankton & -0.129 & 0.017 & $Y=-0.5181 X+10.4$ & 0.135 & 0.723 \\
\hline $\mathrm{CO}_{2}$ - Plankton & 0.0927 & 0.008 & $\begin{array}{l}Y= \\
0.4656 X+8.7155\end{array}$ & 0.06939 & 0.799 \\
\hline pH- Plankton & 0.1326 & 0.0175 & $Y=0.328 X+6.7497$ & 0.143 & 0.715 \\
\hline TA -Plankton & -0.405 & 0.164 & $\begin{array}{l}Y=- \\
0.0405 X+12.657\end{array}$ & 1.57 & 0.25 \\
\hline
\end{tabular}

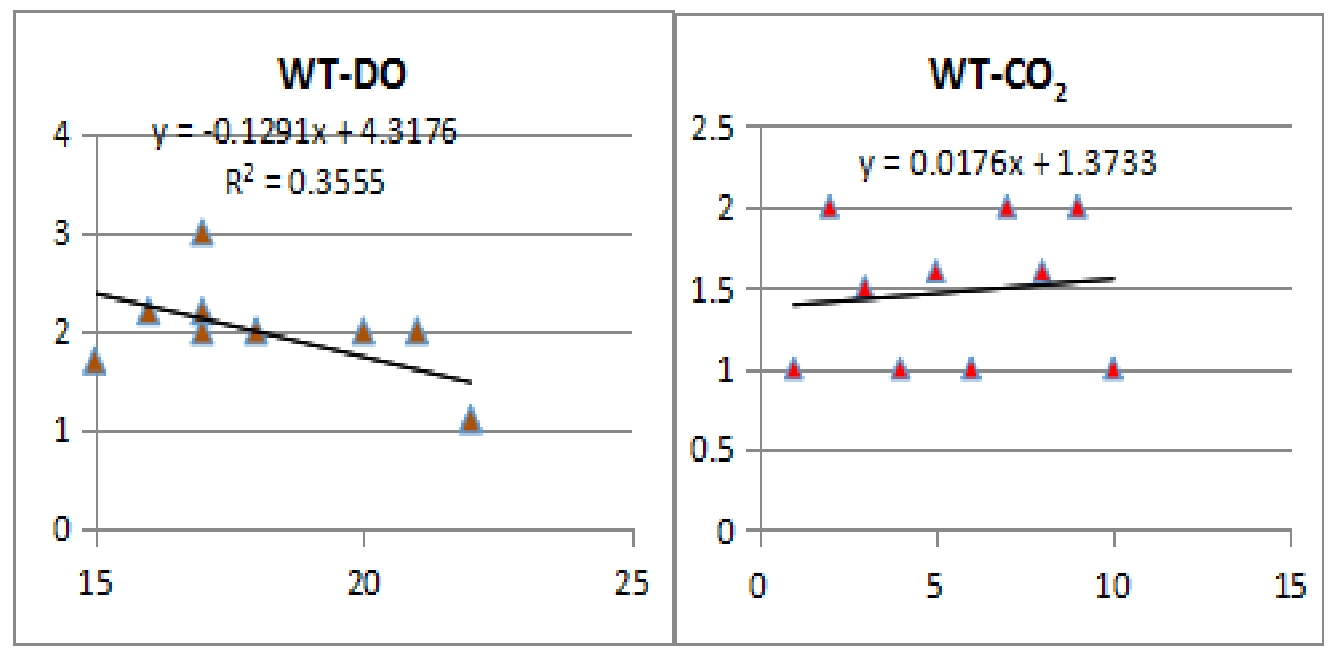



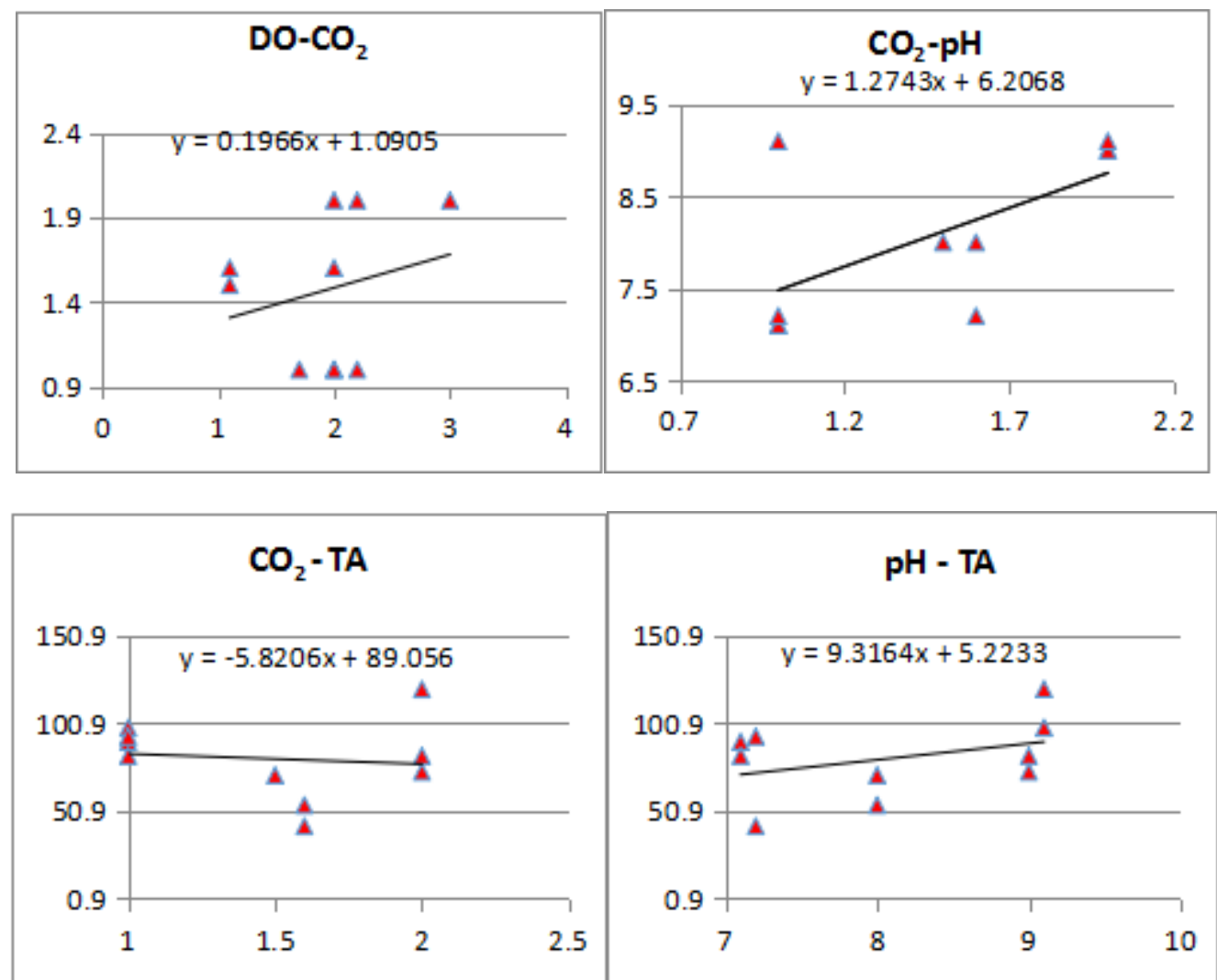

Fig.. 1. Regression analysis between different abiotic parameters in Veer Bhadra barrage, Rishikesh.
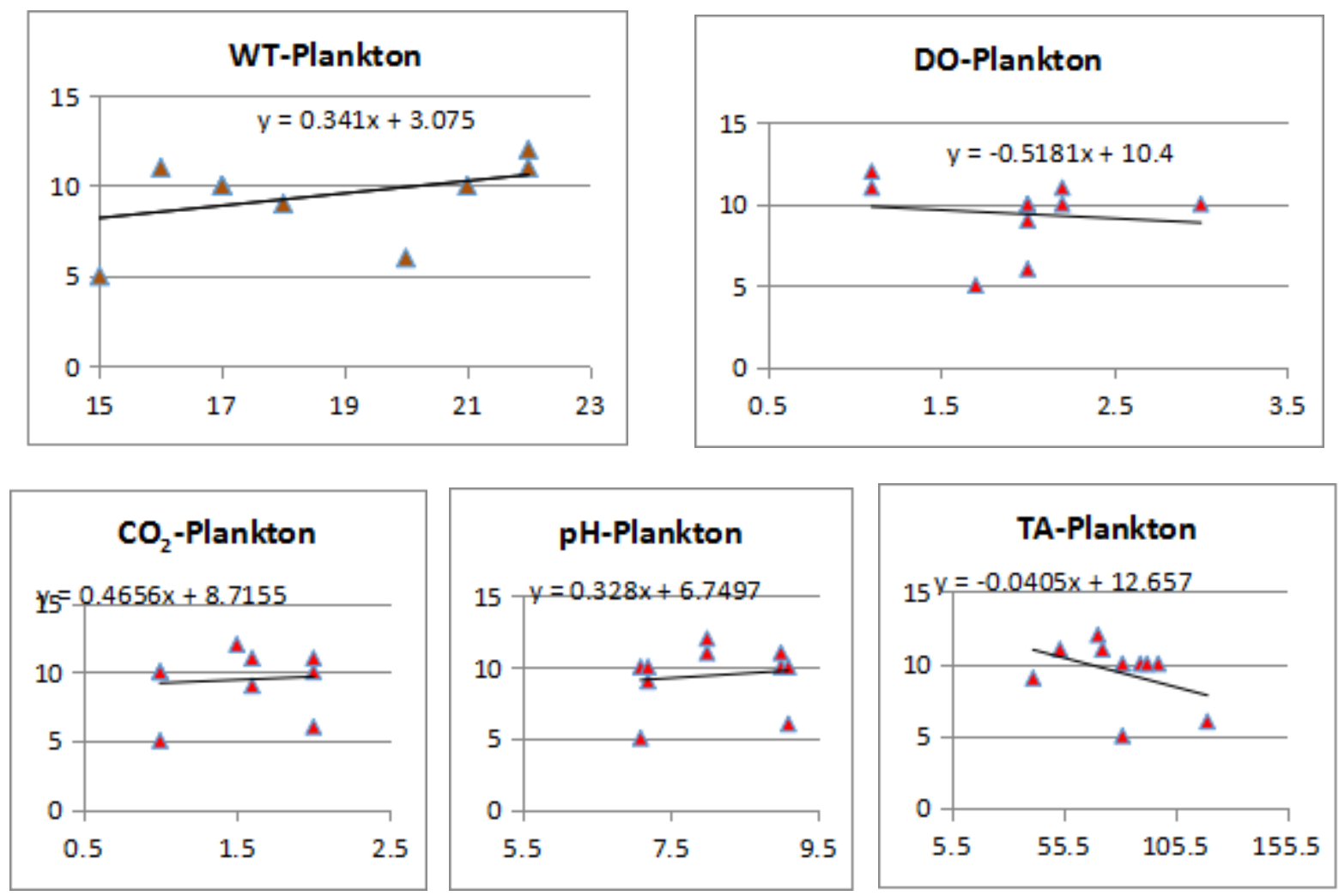

Fig 2: Regression analysis between abiotic parameters and Plankton in Veer Bhadra barrage, Rishikesh. 


\section{Discussion}

The role of individual components has always been a subject of intensive study. Past studies have considered water current to be detrimental for growth of diatoms in particular and biota in general (Kofoid 1908, Hora 1922, Berner 1951). Allen (1920) was of the view that currents above moderate speed are detrimental to plankton development. Similarly, the duration of light penetration (Gran 1902, Patrick 1948) which refers to transparency/turbidity was also considered to have adverse impact on plankton density (Welch 1952, Roy 1955). In the Himalayan rivers high velocities and turbidity were considered detrimental and lethal factors for plankton development as high densities were observed during period of moderate current velocities, low water temperatures and turbidity (Nautiyal 1984). These observations formed the basis of classifying network of rivers and streams having glaciers or springs at their source into turbulent-stenothermal (T-S) and placid-eurythermal (P-E) the reasons for which were discussed in detail by Nautiyal (1986). Earlier the Himalayan rivers were simply designated on the basis of source as snowfed or springfed or as trout, snow trout and mahseer streams (Jhingran and Sehgal 1978, Joshi et al 1978).

Hence, these are the "key factors" influencing quality and quantity of biota in the Himalayan section of the Ganga river system. Their interrelationships are scarcely investigated. They could also be used as surrogate for river health as changes in biota (both qualitative and quantitative) would affect their relationships depicted by regression analysis, in the fashion similar to length-weight relationship. Nautiyal and Lal (1978, 1981), Singh et al (1982) observed $-\mathrm{ve}$ and +ve relationship between WT- $\mathrm{CO}_{2}$ and WT-DO respectively based on correlation coefficient for these set of characteristics. An inverse co-relationship of DO with water temperature was reported in the river by Pathani and Upadhyay (2006).

Although the role of the water temperature in regulating DO profiles is established it was found to be non-significant in placid eurythermal systems. WT-DO maintains a negative relationship in T-S and P-E type of streams. It was found to be significantly related in T-S system only as evidenced by ' $r$ ' and 'b' (Nautiyal et al 1993). The CV appears to be more related to $\mathrm{T}$ than to water temperature. In the P-E systems $\mathrm{T}-\mathrm{DO}$ is a factor of less significance. It becomes clear from the above that water velocity current is more operative in T-S system, while $\mathrm{T}$ in both systems. DO was found to be negatively correlated to WCV and WT.

Relationship based on ' $r$ ' has been reported for various other parameters. Strong significant negative correlation of DO with free $\mathrm{CO}_{2}$ was reported by Joshi et al.(2009) . Matta (2014) reported that the $\mathrm{pH}$ has positive correlation with DO at site 1 (Shivpuri), whereas $\mathrm{pH}$ has positive correlation with total hardness at site 2 (Pashulok barrage). Correlation analysis between the physico-chemical parameters of the Ganga river at both sites (Rishikesh and Haridwar) showed a certain correlation. Strong 
+ve correlation was found for BOD-WT and $\mathrm{TH}$ with $\mathrm{Ca}$ and $\mathrm{Mg}$ hardness. Correlation was found to be negative for DO-BOD and DOCOD. All parameters showed a strong correlation with each other (Tyagi et al. 2020).

Nautiyal (1985) observed total alkalinity did not have any significant relationship with percentage occurrence of green algae as is the case with $\mathrm{CO}_{2}$ and DO. Pathak and Bhatt (1993) noted a good correlation between TDS and conductivity in Kumaun rivers. Based on regression analysis they concluded that the concentration of total hardness was due to calcium and sodium ions. D.R. Khanna et al. (1993), observed a negative relationship between water temperature, phytoplankton and zooplankton density? An inverse relationship between temperature and dissolved oxygen was observed in the present study which lends support to the observations made by Dobriyal and Singh $(1988,1989)$ in the rivers Nayar and Mandakini.

With respect to plankton a negative relationship was observed between water temperature and phytoplankton $(\mathrm{r}=-0.8416)$ and zooplankton $(r=-0.6925)$. A very high negative correlation was observed between velocity and phytoplankton $(r=-0.9827)$. An inverse relationship was also observed between BOD and DO and consequently between BOD and plankton also. The coefficient of correlation was -0.974 between BOD and phytoplankton and -0.932 between BOD and zooplankton. Free carbon dioxide showed a negative correlation with plankton (phytoplankton: $\mathrm{r}=-0.88$, zooplankton: $\mathrm{r}=$ -
0.659). However, the DO had a highly positive correlation with phyto- $(\mathrm{r}=+0.992)$ and zooplankton $(\mathrm{r}=+0.943)$. The plankton assemblage consisted of Bacillariophyceae, Chlorophyceae, Cyanophyceae, Crustaceans and rarely by the rotifers (Nautiyal 1985, Dobriyal et al 1993, Bist 1993).

It augurs from the above discussion that most relationships have been defined by the coefficient of correlation (r) without considering its level of significance. Hardly any study has used coefficient of regression (b) to understand the nature of relationship and that too without examining their level of significance which is a measure of accuracy or robustness of the estimate. In the present study plankton showed -ve relationship with DO and total alkalinity, but lacked significance. The relationship with other factors though +ve also lacked significance, hardly exhibiting any relationship. Nautiyal et al (1993) found significant ' $r$ ' for all examined set of abiotic factors in the glacierfed (T-S rivers) such as Alaknanda, Bhagirathi, Ganga and springfed Nayar, Khurmola and Asiganga (P-E streams), barring WC-DO, WT-DO, WC-T, T-DO in some P-E streams. Both coefficients ( $r, b)$ were mostly insignificant (except WT-DO) when applied collectively to T-S and P-E systems which suggest need for suitable statistical technique such as multivariate analysis where role of factors can be graded.

Conclusion: Unlike the independent rivers cited above, all set of abiotic parameters in the Ganga at veer-Bhadra exhibited poor or insignificant correlation (r) and hence 
regression coefficients (b). This can be possibly attributable to loss of ecosystem structure and function caused by impounding the Ganga at Veer-Bhadra barrage. Robust relationships are expected in pristine ecosystems while no or poor relationships in modified ecosystems.

\section{Acknowledgements}

Authors are grateful to the anonymous reviewers for giving present shape to the manuscript.

\section{References}

Allen W E (1920). A quantitative and statistical study of the plankton of the San Joaquin river and its tributaries in and near Stockton, California. Univ. Callif. Publ. Zool, 22, 1-292.

Berner LM (1951). Limnology of the lower Missouri River. Ecology 32, 1- 12.

Bist K L (1993). Environmental parameters and seasonal succession in planktonic biomass in the river Pinder of Garhwal Himalaya, p. 163170. In: Singh H R ed. Advances in Limnology, Narendra Publishing House, Delhi.

Dobriyal AK (1985). Ecology of limnofauna in the small stream and their importance to the village life in Garhwal Himalaya. Uttar Pradesh Journal of Zoology 5, 139-144

Dobriyal A K and Singh H.R. (1988). Ecological basis for ichthyofaunal variation in two hillstreams of Garhwal Himalaya. In: M Mohan Joseph ed. The First Indian Fisheries Forum, Proc. Asian Fish. Soc. Indian Branch, Mangalore 313-317.

Dobriyal A K and Singh H.R. (1989). Observations on temporal trends of phytoplankton diversity in the river Nayar of Garhwal Himalaya. J. Freshw Biol. 1, 1-6
Dobriyal A K, Bahuguna A K, Kumar N and Kotnala C B (1993). Ecology and seasonal diversity of plankton in a springfed stream Khandagad, p. 175180. In: Singh H R ed. Advances in Limnology Narendra Publishing House, Delhi.

Garnett W G(1953). Freshwater microscopy. Constable and CO. LTD. 10-12 Orange Street WC -2 .

Gran H H (1902). Das Plankton der Norweigischen Nordmeers von biologischen Behandle. Rep Norweigh Fish Marine Inv 2, 1-222.

Hora S L (1922). Structural modifications in fish of mountain torrents. Rec Indian Mus 24, 31-61.

Hynes, HBN(1970). The Ecology of Running Waters. Liverpool University Press 555.

Jhingran G and Sehgal K L (1978) Coldwater Fisheries of India. Inland Fish Soc. India, Barrackpore.

Joshi C B, Sehgal K L and Sunder S (1978). Observations on the fishery resources of the hillstreams of Jammu Province with special reference to mahseer and' other commercially important species. Indian J Fish. 25(1 \& 2), 197-206.

Joshi, DM Bhandari, N.S. Kumar A and Agrawal N. (2009).Statistical analysis of physico-chemical parameters of water of river Ganga in Haridwar. Rasayan J.Chem. 2(3): 579-587.

Khanna D R . Badola S P and Dobriyal A K (1993). Plankton ecology of the Ganga at Chandighat, p. 171-174 In: Singh $H \quad R$ ed. Advances in Limnology, Narendra Publishing House, Delhi.

Kofoid CA (1908). The plankton of Illinois river 1894-1899 with introductory notes upon the hydrography of the Illinois river and its basin. II. Constituent organisms and their seasonal distribution. Bull. Illinois Lab Natl Hist. 8, 1-355. 
Matta G (2014). A study on physico-chemical characteristics to assess the pollution status of river Ganga in Uttarakhand. J. Chem. and Pharm. Sci.7(3), 210217

Nautiyal P (1984). Studies on the riverine ecology of the torrential waters in Indian uplands of Garhwal region. 2. Seasonal fluctuations in diatom density. Proc Indian Acad Sci (Anim Sci) 93, 671-674.

Nautiyal P (1985). Studies on the riverine ecology of the torrential waters in Indian uplands of Garhwal region. 1. Seasonal variations in the percentage occurrence of planktonic algae. Uttar Pradesh J. Zool. 5(1), 14-19.

Nautiyal P (1986). Studies on the riverine ecology of the torrential waters in Indian uplands of Garhwal region. Floristic and faunistic survey Tropical Ecology 27, 157-165.

Nautiyal P and Lal M S (1978). Ecobiological studies on some hillstream fishes of GarhwalHimalaya:3.Hydrobiological factors and their bearing on the productivity of Mahseer in the hillstream Alaknanda, Mandakini and Nayar. Indian J. Zoot. 19, 21-27.

Nautiyal P and Lal M S (1981). Limnological studies on the stream of Garhwal Himalaya 2. Variation in water chemistry of Eastern Nayar. Indian J. Zoot. 22, 133-135.

Nautiyal P, Agarwal NK \&Singh H R (1993). Certain abiotic components of the fluvial system and their interrelationships as evidenced by statistical evaluation $\mathrm{p}$ 181-186. In: Singh $H \quad R$ ed. Advances in Limnology Narendra Publishing House, Delhi.

Negi K. S, D.S. Malik and P.K. Bharti (2006). Impact of river flow regulation on the Planktonic population in Ganga river at Rishikesh (Uttaranchal). Environment conservation journal 7(1-2)55-58.
Patrick R (1948). Factors effecting the distribution of diatoms. Bot. Rev. 14, 473-524

Pathak JK and Bhatt SD (1993). Physicochemical characteristics of three major riverine waterbodies in the uplands of Kumaun, Central Himalaya, p. 145-168. In: Singh H R ed. Advances in Limnology, Narendra Publishing House, Delhi.

Pathani SS and Upadhyay KK (2006). An inventory on zooplankton, zoobenthos and fish fauna in the river Ramganga (W) of Uttaranchal, India. Kumaon University, ENVIS Bulletin: Himalayan Ecology 14(2). $37-46$

Rautela KK, Kumar K, Bisht KL, Joshi VD, Negi KS and Dobriyal AK (2006). Ecological studies on the biodiversity of river Khoh in the foot hills of Garhwal Himalaya, Part 2: macrozoobenthic analysis. Aquacult 7(2): 277-283

Roy HK (1955). Plankon ecology of the river Hooghly at Palta. Ecology 36, 169175.

Singh HR.and Dobriyal AK (1981). Potamology of the stream 'Chakagadera' in relation to the productivity of cold water minor carps in Garhwal Himalaya. Proc. Indian Natn Sci. Acad. B47(5), 652655 .

Singh HR, Badola SP and Dobriyal AK (1982). Ecology of the river Nayar of Garhwal Himalaya. Uttar Pradesh J. Zool. 2, 72-76.

Tyagi S., Dubey. RC, Bhutiani R, Ahamad F (2020). Multivariate statistical analysis of river Ganga water at Rishikesh and Haridwar, India. Analytical Chemistry Letters 10(2), 195-213.

Welch P S (1948). Limnological Methods. The Blackiston Co., Philadelphia.

Welch PS (1952). Limnology. McGraw-Hill, New York. 